UDC 577.27

\title{
DESIGNING, DOCKING AND HETEROLOGOUS EXPRESSION OF AN ANTI-HER2 AFFIBODY MOLECULE
}

\author{
N. SALMANIAN TABASI ${ }^{1}$, A. GHOLIZADEH ${ }^{1}$, B. BAGHBAN KOHNEHROUZ 2 \\ ${ }^{1}$ Research Institute for Fundamental Sciences, University of Tabriz, Iran; \\ ${ }^{2}$ Department of Plant Breeding and Biotechnology, University of Tabriz, Iran; \\ e-mail: aghz_bioch@yahoo.co.in
}

\begin{abstract}
Affibody molecules are small protein scaffolds mostly based on triple-helical bundle protein domains. Many triple helix-based affibody proteins have shown prominent properties for tumor imaging and therapy. In our opinion, the structural organizations and the sizes of affibody molecules could be modified to increase their recognition abilities and binding affinities to human epidermal growth factor receptor type 2 (HER2). Thereby, the purpose of this study was to design and characterize a novel platform of affibody molecule consisting of five separate helixes (encoding 99 amino acids with a duplicate of helixes 1 and 2 at $N$-terminus plus GGGC chelator peptide sequence at C-terminus) enable of binding to HER 2 with higher avidity. Using in silico screening methods, the structure and the interactive potential of designed affibody was comparatively investigated. The molecular expression and production of the designed affibody in Escherichia coli cells was successfully examined and reported.
\end{abstract}

Key words: affibody, HER2 receptor, molecular docking, protein expression.

A

ffibody molecules are known as small protein scaffolds or affinity proteineous ligands that are mostly based on triple-helical bundle protein domains. Among them, triple helix bundle $\mathrm{Z}$ domain-based scaffolds constitute a novel class of affibody molecules which are the engineered synthetic variants of the B domain of staphylococcal protein A (SPA) [1]. The Z-affibody is a relatively short cysteine-free peptide consisting of 58 amino acid residues. In compare to antibody molecules with the molecular sizes of about $150 \mathrm{kDa}$, it has got molecular weight of about $6 \mathrm{kDa}$ that is so smaller than antibody molecule [2]. $\mathrm{Z}$ affibodies are known as the most favorable affinity ligands for therapeutic, diagnostic and biotechnological applications, due to their fast reversible folding, high solubility, covalent modification and ability for the high level of production in E. coli cells [2,3]. The combinatorial libraries of affibody molecules could be easily constructed by randomization of 13 amino acid residues in the 1st and 2th helixes of $Z$ domain [3,4]. These helixes are involved in molecular recognition process while, helix 3 provides the structural stability [4]. To date, numbers of high affinity affibody molecules specific for different target proteins such as fibrinogen, insulin [5], transferrin, tumor necrosis factor $\alpha(\mathrm{TNF} \alpha)$ $[6,7]$, IL-8, gp120, CD28, human serum albumin, IgA, IgE, IgM, human epidermal growth factor receptor type 2 (HER2) $[8,9]$ and epidermal growth factor receptor EGFR $[10,11]$ have been reported.

Human epidermal growth factor receptor type 2 (HER2) is a transmembrane tyrosine kinase receptor that regulates cell proliferation, differentiation, motility, adhesion, and apoptosis [12]. The human epidermal growth factor expression is increased in various malignant tumors (e.g., breast, colon, bladder, lung, gastric and prostate cancer cells) resulting in increased cell proliferation and decreased apoptosis $[13,14]$. Thus, identification of these receptors in cells helps us to distinguish cancer cells from normal tissues. Affibody molecules have recently emerged as a unique class of tumor targeting agents for molecular imaging and diagnosis. Newly, four human papilloma virus (HPV16 E7)-binding affibody molecules (namely $Z_{\mathrm{HPV} 16 \mathrm{E} 7} 127, Z_{\mathrm{HPV} 16 \mathrm{E} 7} 301, Z_{\mathrm{HPV} 16 \mathrm{E}} 7384$ and $\left.Z_{\mathrm{HPV} 16 \mathrm{E} 7} 745\right)$ have been screened from a phage-

(C) 2018 N. Salmanian Tabasi et al. This is an open-access article distributed under the terms of the Creative Commons Attribution License, which permits unrestricted use, distribution, and reproduction in any medium, provided the original author and source are credited. 
displayed peptide library and used for molecular imaging in tumor-bearing mice [15]. As a powerful targeting probe for the tumor diagnosis and imaging in human, various $\mathrm{Z}$ affibody molecules with specific affinities for HER2 receptor including ZHER2:4 [7], ZHER2:477 and ZHER2:342 [8], ZHER2:2395 [16] and ZHER2:2891 [1] and ZHER2:2Helix [2, 4, 11, 17] have been developed and utilized [18]. Recently, the Cy5.5-labeled ZHER2:342 affibody molecules have been utilized for the fluorescent optical imaging of epidermal growth factor receptor positive tumors [19]. The same affibody molecule was recently used as anti-HER2-PNA (peptide nucleic acid) chimera for radioimmunotherapy in which the contrast between tumor and normal tissues was improved by primary targeting agent conjugated to a recognition tag and a secondary tag-bound radio-labeled molecule [20].

Besides the identification of the native interactive structures, designing and easy way of production of the novel proteins or peptides are now challenging tasks for molecular biologists. The most of the interactive structures regulate the sensitive biological activities such as signal transductions, immune responses, and enzymatic activities. Therefore, attempts are mostly taken to improve their folding properties, the molecular sizes as well as the stabilities of the interactive structures. The molecular designing may lead to the discovery of the new and strategic therapeutic targets or drugs [21, 22]. Although, many of the structures are determined by $\mathrm{X}$-ray crystallography and nuclear magnetic resonance (NMR) spectroscopy but, due to the high cost and technical limitations, computational molecular docking, modeling and simulation methods are now being used to facilitate the in vivo bio-functional studies. Thereby, using these tools, different types of specific affibodies can be easily designed, synthesized and biologically evaluated.

Considering all these together, we aimed to combine two different modifications (based on the structures of ZHER2:2891 and the last modified ZHER2:342) in one affibody molecule and alter its molecular size (by duplication) to increase its interaction and binding ability to HER 2 receptor molecule. The interaction analysis and binding energy calculations were performed by computational tools. Using gene cloning and expression technologies, the newly synthesized affibody molecule was successfully expressed in an Escherichia coli expression system without affecting the bacterial growth pattern.

\section{Materials and Methods}

Designing and docking of affibody molecule. Based on the structures of ZHER2: 2891 and the last modified ZHER2: 342 affibody molecules $[11,23,24]$, an anti-HER 2 affibody molecule containing 99 amino acids (HMCAK EMRNA YWEIA LLPNL TNQQK RAFIR KLYDD PCPME AKYAK EMRNA YWEIA LLPNL TNQQK RAFIR KLYDD PSQSS ELLSE AKKLN DSQGG GCLE ) with the C-terminal sequence of GGGC and 2 additional helical structures was designed.

Three dimensional structure of molecule was obtained by phyre v. 2.0 (http://www.sbg.bio.ic.ac. uk/phyre2) a web-based 3D protein structure prediction server [25]. The obtained structure was saved as pdb format. For further analysis, the minimized model was performed and validated using Ramachandran plots obtained from RAMPAGE (http:// mordred.bioc.cam.ac.uk/ rapper/rampage.php).

The crystal structure of HER2 (PDB ID: 1N8Z), was extracted from the Protein Data Bank (PDB) (http://www.pdb.org). The extra parts of the molecule were removed from the crystal structure using gedit software.

The molecular docking analysis of the designed affibody with HER 2 molecule was carried out by Rosetta v. 3.5 software (http://rosettadock.graylab. jhu.edu). Its interactive structure and its minimized binding energy were compared with those of triple and double helical affibody molecules. The best possible binding affinities of the HER2 at target protein were obtained by using PYMOL computational tool. The schematic diagrams of protein-protein interactions were generated by using LIGPLOT program v. 1.4.

Bacterial strains, plasmids and chemicals. DH5 $\alpha$ and BL21 (DE3) E. coli strains were provided from laboratory stock and used as the hosts for recombinant plasmid. DH5 $\alpha$ strain used for cloning and BL21 (DE3) strain carrying the T7 RNA polymerase gene used for the purposes of protein expression and production. pET-26b $(+)$ vector containing C-terminus His-Tag and $\mathrm{T} 7$ promoter (Cat. No. 69862-3) was used as the expression vector. Gel Extraction kit (Cat. No. K-3035-1; Bioneer) utilized for the extraction of DNA from the gel materials. Plasmid Miniprep kit (Cat. No. K-3112; Bioneer) used for plasmid isolation and purification from transformed recombinant cells. Restriction enzymes NdeI and XhoI and T4 DNA Ligase were purchased 
from Bioneer. All of the other chemicals used in this study were of molecular biology grades.

Cloning and expression of designed pET-26b (+)-affibody molecule. The gene of the affibody molecule consisting of 99 amino acids was synthesized by GENErey biotechnology company (generay.com.cn). The synthesized product and pET-26b vector were double-digested by NdeI and XhoI restriction endonucleases for $1.20 \mathrm{~h}$ at $37^{\circ} \mathrm{C}$. Then digested fragments were separated electrophoretically on $0.8 \%$ agarose gel stained with red safe dye. The desired components were purified from the gel according to Bioneer gel extraction kit protocol and ligated to each other using T4 DNA ligase. For this, $15 \mu \mathrm{l}$ of purified double-digested pET-26b(+) and $5 \mu 1$ of insert were incubated with T4 DNA ligase enzyme in 10x T4 DNA ligase buffer at $22^{\circ} \mathrm{C}$ for $1 \mathrm{~h}$. The ligated reaction was transformed into the competent $\mathrm{DH} 5 \alpha$ cells by using transformation and storage solution (TSS) containing kanamycin $(50 \mu \mathrm{g} / \mathrm{ml})$.

Plasmid vectors were isolated from transformed cells and confirmed by double digestion and separation on the agarose gel. For further confirmation, the selected recombinant plasmid was purified and subjected to sequence analysis. In order to express the selected recombinant vector, it was transformed into the BL21 (DE3) E. coli strain [26].

SDS-PAGE analysis. For polyacrylamide electrophoresis analysis, the crude proteins of recombinant and non-recombinant cells were separately isolated through the bacterial lysis in TES buffer (containing $20 \mathrm{mM}$ Tris, $5 \mathrm{mM}$ EDTA and 10\% Sucrose) by three times homogenization at $25000 \mathrm{rpm}$ for $30 \mathrm{Sec}$. For high yield protein extraction, the bacterial lysis was performed in the presence of SDS. SDS-PAGE analysis SDS-PAGE analysis was performed using $(12 \%)$ polyacryamide gels and protein samples were stained by Coomassei Brilliant Blue dye along with the molecular weight standards. Protein samples were heat treated at $100{ }^{\circ} \mathrm{C}$ for $4 \mathrm{~min}$ and aliquots of $50 \mu \mathrm{g}$ of total protein extract were loaded. The gel was run for $2 \mathrm{~h}$, stained by staining buffer containing acetic acid, methanol, distilled water and coomassie blue, followed by incubation in destaining buffer containing acetic acid, methanol and distilled water for visualization and protein detection [27].

Western blot analysis. Protein profile on SDSPAGE was transferred onto nitrocellulose membrane using $0.025 \mathrm{M}$ Tris- $\mathrm{HCl}$ ( $\mathrm{pH}$ 8.3) blotting buffer supplemented by 0.192 M Gly and $20 \%$ ethanol. The blot was kept in TBS-BSA containing $0.02 \mathrm{M}$ Tris-
$\mathrm{HCl}(\mathrm{pH} 7.5), 0.5 \mathrm{M} \mathrm{NaCl}$ and $1 \%$ BSA. Then it was incubated with specific anti-His tag antibody at the ratio of $1: 500$ at $37^{\circ} \mathrm{C}$ for $2 \mathrm{~h}$. After washing with Tween 20 containing TBS buffer, the membrane treated with goat anti-rabbit antibody conjugated with alkaline phosphatase at the ratio of $1: 20000$. The Western signal was visualized with $400 \mathrm{mM}$ nitro-blue-tetrazolium- chloride (NBT) and $500 \mathrm{mM}$ bromo-chloro-indolyl-phosphate (BCIP) in $0.1 \mathrm{M}$ Tris- $\mathrm{HCl}$ (pH 9.5) containing $0.1 \mathrm{M} \mathrm{NaCl}$ and $5 \mathrm{mM}$ $\mathrm{MgCl}_{2}$.

Bacterial growth assay. To investigate the possible effects of recombinant affibody expression on transgenic bacteria, the growth patterns of recombinant and non-recombinant bacteria were assessed spectrophotometericaly. For this purpose, a single clone of transgenic bacteria and a single clone of non-transgenic bacteria were separately incubated in $50 \mathrm{ml}$ of LB liquid medium containing the antibiotic kanamycin and then held at $180 \mathrm{rpm}$ in a Shaker incubator for 14-16 h. In order to induce the recombinant protein expression, IPTG inducer was added to each sample and the absorbance of the each sample was measured at $600 \mathrm{~nm}$ by using Reyleigh UV/VIS scanning spectrophotometer.

\section{Results and Discussion}

Designing and docking studies of affibody molecule. The typical affibody molecules including the already reported anti-HER2 affibodies all are composed of triple helix bundle in which helixes 1 and 2 are involved in the binding ability of the molecule and consisted of 11 and 12 amino acids, respectively [4]. In order to increase the binding affinity of an anti-HER 2 affibody to its receptor, we designed an affibody molecule with 99 amino acids that exhibit higher interactive ability for HER2. This molecule was designed on the bases of ZHER2:2891 affibody molecule and composed of helixes 1 and 2 duplicate at $\mathrm{N}$-terminus position and helix 3 at C-terminus. Thereby, despite of typical anti-HER2 affibody molecules, it was designed to compose of five separate helixes. In addition, same to last modified ZHER2:342, to enable the chelating and stable labeling for specific targeting or imaging purposes, a tetra peptide sequence "GGGC" was located at the $\mathrm{C}$-terminus position of the affibody molecule. Besides these, the NdeI, XhoI and NcoI restriction enzyme sites were also designed and located at the Nterminal, $\mathrm{C}$-terminal and in the middle parts of the affibody gene, respectively (Fig. 1, A and B). NdeI, 
$\boldsymbol{A}$

CATATG TGC GCG AAA GAA ATG CGC AAC GCG TAT TGG GAA ATT GCG CTG CTG CCG AAC CTG ACC AAC CAG CAG AAA CGC GCG TTT ATT CGC AAA CTG TAT GAT GAT CCG TGC CCCATG GAA GCG AAA TAT GCG AAA GAA ATG CGC AAC GCG TAT TGG GAA ATT GCG CTG CTG CCG AAC CTG ACC AAC CAG CAG AAA CGC GCG TTT ATT CGT AAA CTG TAT GAT GAT CCG AGC CAG AGC AGC GAA CTG CTG AGC GAA GCG AAA AAA CTG AAC GAT AGC CAG GGC GGC GGC TGC $\underline{\text { CTCGAG }}$

B

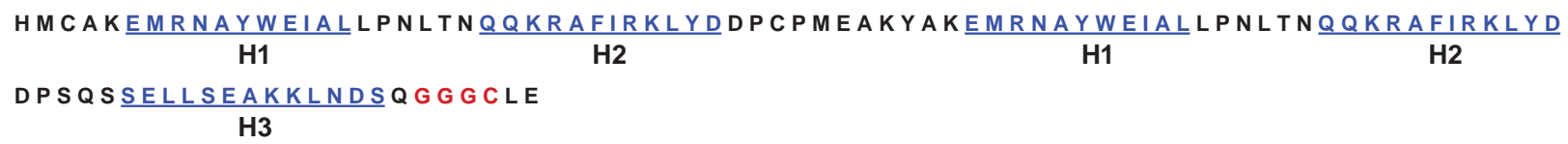

Fig. 1. Nucleotide and predicted amino acid sequence analysis. $\boldsymbol{A}$ - The nucleotide sequence of affibody molecule containing restriction enzyme sites of NdeI, NcoI and XhoI at the N-terminus, middle and C-terminus positions, respectively. $\boldsymbol{B}$-Deduced amino acid sequence of HER2-binding affibody molecule; The positions of five helixes are shown in blue and underlined

XhoI restriction sites were included for the cloning purpose, while NcoI site was considered for the handling of the size of the designed molecule for further studies.

The three-dimensional structural organization of the designed affibody molecule was predicted by internet-based Phyre 2 online server. The result showed that the 3D structure of designed affibody molecule is consisted of five separate helixes (Fig. 2, A). The predicted structure was further validated by using Ramachandran plot with PROCHECK program (Fig. 2, B). Analysis of the results related to the torsion angels $\Psi$ and $\Phi$ showed that $85 \%$ of the amino acid residues are located in most favored region, $12.5 \%$ of the residues in allowed region, $1.2 \%$ of the residues in generously allowed region and $1.2 \%$ of the residues in outlier region. The $3 \mathrm{D}$ interactive model of this affibody with domain 3 of HER2 molecule was displayed by using PYMOL v. 1.1 computational tool and found to be in consistent to the previous report with regard to typical triple helix affibody (Fig. 2, C).

Human HER 2 receptor is known as member of tyrosine kinase protein family that contains the binding site for affibody molecules. As a comparative study, the molecular interaction of the designed affibody with HER2 receptor was performed by using Rosetta molecular docking server and compared with those of double and triple helical ZHER:2891 affibody molecules (without and with helix 3 ) based on their calculated energy of interaction or binding energies (Fig. 2, D). The lowest docked-energy of -1371.1 was found to be related to five helical affibody molecule in comparison to -863.8 and -856.4 for triple and double helical analogs, respectively.
This data revealed us there is considerable difference between the binding energies of double and triple helixes based structures and five helical affibody with HER 2 receptor molecule. The five helical affibody molecule was predicted to be interacted 1.6 times more than double or triple helical analogs.

Using the bioinformatics LIGPLOT prediction server, the bond lengths and the amino acid residues involved in protein-protein interactions were generated. The obtained 2D representative results showed that the amino acid residues " $\mathrm{Asn}^{22}, \mathrm{Ala}^{15}, \mathrm{Leu}^{17}$, $\mathrm{Phe}^{27}, \mathrm{Lys}^{25}, \mathrm{Ile}^{14}, \mathrm{Tyr}^{51}$, Glu13, Arg ${ }^{48}, \mathrm{Asn}^{49}, \mathrm{Asp}^{62}$, $\mathrm{Lys}^{65}, \mathrm{Glu}^{99}$ and Leu ${ }^{98 "}$ from affibody molecule are interacted with the amino acid residues "Pro" $\mathrm{Ala}^{317}$, Glu298, $\mathrm{Val}^{319}, \mathrm{Arg}^{318}, \mathrm{Tyr}^{321}, \mathrm{Glu}^{326}, \mathrm{Arg}^{329}$, $\mathrm{Glu}^{341}, \mathrm{Ala}^{337}$, Thr ${ }^{335}, \mathrm{Thr}^{367}, \mathrm{Asn}^{366 "}$ from HER2 receptor molecule (the output graph not presented). The previous reports concerning to the interaction analysis have shown that affibody molecules bind to domain 3 of human HER 2 receptor [11, 23]. Evaluation of bound amino acid residues showed that our LIGPLOT data is in agreement with the previous results and furthermore confirmed the binding ability of HER2 through its domain 3.

Expression study of designed affibody molecule. The inserted affibody gene in pET-26 b (+) vector as recombinant vector was transformed into E. coli DH5- $\alpha$ competent cells and selected on LBagar medium supplemented with $50 \mu \mathrm{g} / \mathrm{ml}$ of kanamaycin. Transformed bacteria were characterized by the extraction of plasmid DNA and double digestion with NdeI and XhoI. The results were detected by agarose gel electrophoresis (the gel photograph not presented). To confirm the inserted affibody gene, the recombinant pET26b plasmid was sent 
$A$

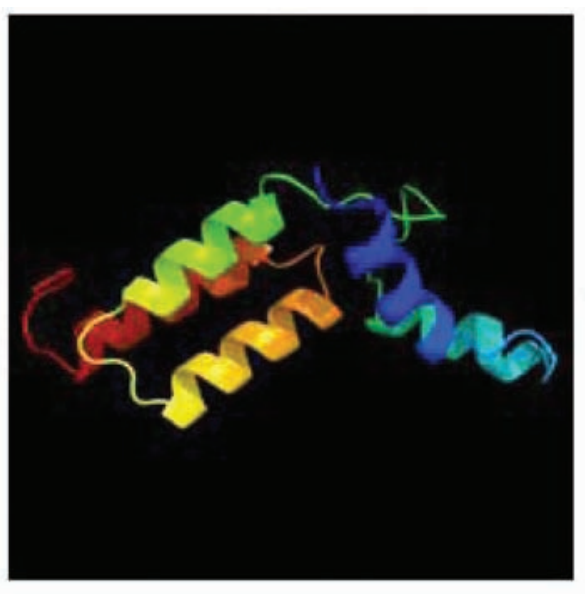

C

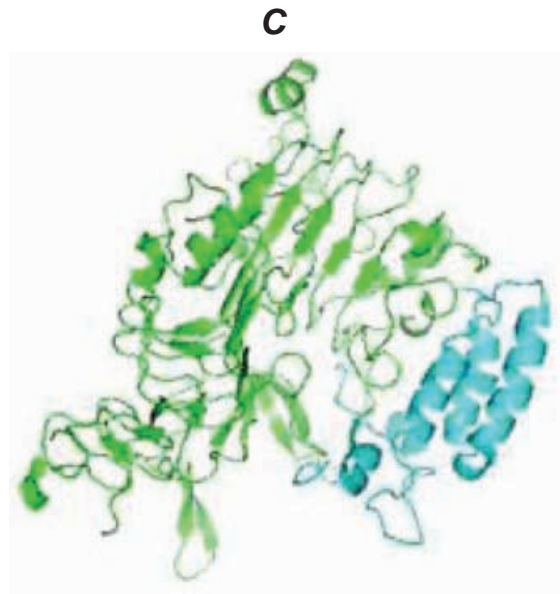

B

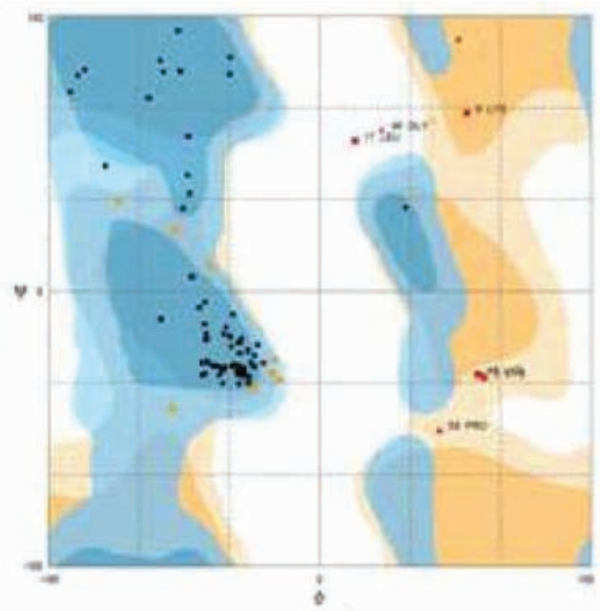

D

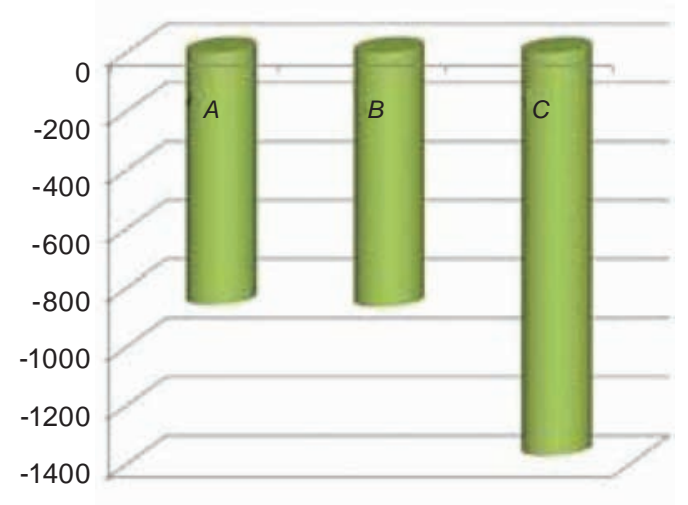

Fig. 2. 3D Structure and molecular docking analysis. A - Predicted three dimensional structure of modified affibody by phyre v. 2.0 server. $\boldsymbol{B}$ - Ramachandran plot distribution model computation of modified five helical affibody molecule through the psi/phi angle calculated by RAMPAGE program; $\boldsymbol{C}$ - Interactive structure of five helical affibody (cyan) with HER2 (green); D - Binding energies of three affibody molecules with HER2: $\boldsymbol{A}$ - The lowest docked-energy of double helical affibody molecule, $\boldsymbol{B}$ - The lowest docked-energy of triple helical affibody molecule and $\boldsymbol{C}$ - The lowest docked-energy of five helical affibody molecule. Green columns represent the weighted scores

for sequence analysis (the sequence results not presented). Then after, the recombinant plasmid was transformed into BL21 (DE3) E. coli strain and the recombinant bacteria were selected on LB medium containing kanamaycin $(50 \mu \mathrm{g} / \mathrm{ml})$.

The recombinant expression of affibody molecule in E. coli cells was tested by SDS-PAGE analysis. Comparison of the relative abundance of the bonds between recombinant and non-recombinant crude protein extracts revealed that the affibody molecule might be expressed as about $14 \mathrm{kDa}$ recombinant protein in E. coli cells (Fig. 3, A). The size of the expressed molecule was consistent with the estimated size of designed affibody molecule. The expression of recombinant affibody was further confirmed by Western blotting using the anti-His tag antibody (Fig. 3, B). An strong signal was detected on recombinat blot lane as compare to that non-recombinat.

To evaluate the possible effect of expressed affibody on $E$. coli cells, the growth rates and patterns of recombinant and non-recombinant bacteria were separately analyzed under induced conditions with IPTG. The growth of bacteria was assessed by measuring the OD of the cultures at $600 \mathrm{~nm}$ for $1 \mathrm{~h}$ time intervals for an overall $5 \mathrm{~h}$ incubation period. 


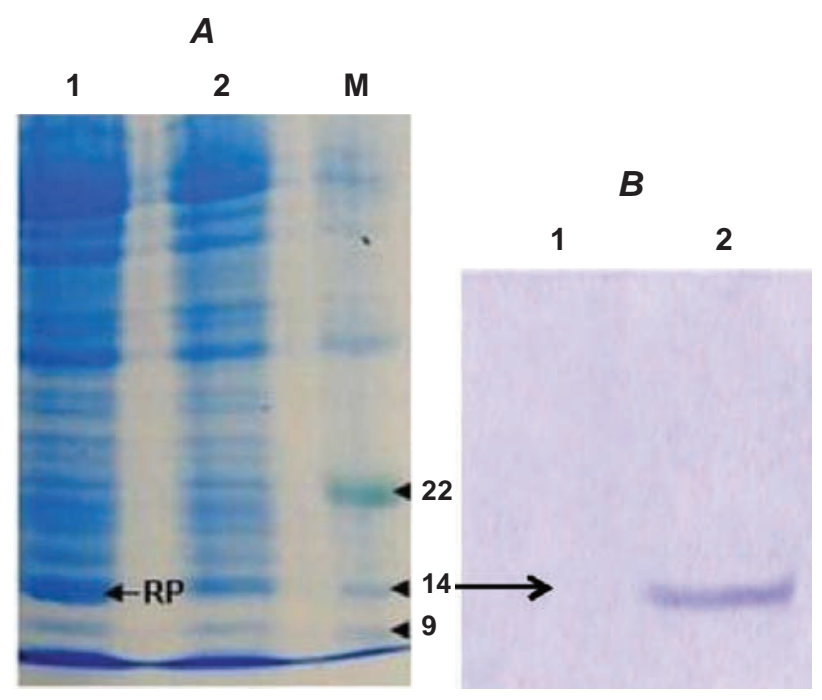

Fig. 3. SDS-PAGE and Western analysis. $\boldsymbol{A}-$ The expression of affibody product was tested by SDSPAGE using $12 \%$ polyacrylamide gel. Lane 1: recombinant expression, Lane 2: non-recombinant expression; $\mathbf{M}$ : molecular weight marker; $\boldsymbol{B}-$ Confirmation of recombinant affibody expression using anti-His tag antibody. Lane 1: non-recombinant expression, Lane 2: recombinant expression showing strong Western signal

The results indicated that the growth pattern of recombinant bacteria is similar to that of non-recombinant cells and it is not affected by the induced expression of affibody molecule in E. coli cells (Fig. 4).

Targeting proteins based on non-immunoglobulin affinity ligands, such as affibody molecules, are currently used for molecular imaging and various detections $[2,19,20]$. The small sizes $(4-15 \mathrm{kDa})$ of these tracers were found to enable efficient imaging contrast and tissue specific molecular detection [11]. Development and evolvement of affibody molecules for molecular imaging has got substantial potential for identification and characterization of various disease-specific biomarkers [4]. To date, different anti-HER 2 affibody molecules have been emerged as a unique and powerful class of tumor targeting agents for molecular imaging and diagnosis against human HER2 receptor [18]. They include ZHER2:4 [7], ZHER2:477 and ZHER2:342 [8], ZHER2:2395 [16], ZHER2:2891 [1] and ZHER2:2Helix [2, 17]. Following these reports, as a different type of anti-HER2 affibody evolvement, its multiplication was mainly considered to increase its binding ability to receptor molecule. For this, the last presented ZHER2:2891 anti-HER2 affibody was selected as base structure. ZHER2:2891 had been previously synthesized with improved properties including thermal and chemical stability as well as increased hydrophobicity by using chemical peptide synthesis and recombinant bacterial expression methodologies. Its improvement been overally achieved by 11 amino acid substitutions in the non-binding surface of native Z-domain [1]. In this work, using in silico methods, a new platform of anti-HER2 affibody molecule having five alpha-helixes (including a duplicate of helixes 1 and 2 at $\mathrm{N}$-terminal plus helix 3 at $\mathrm{C}$-terminal position of ZHER2:2891) was designed. The results of the comparative molecular docking analysis subjected that

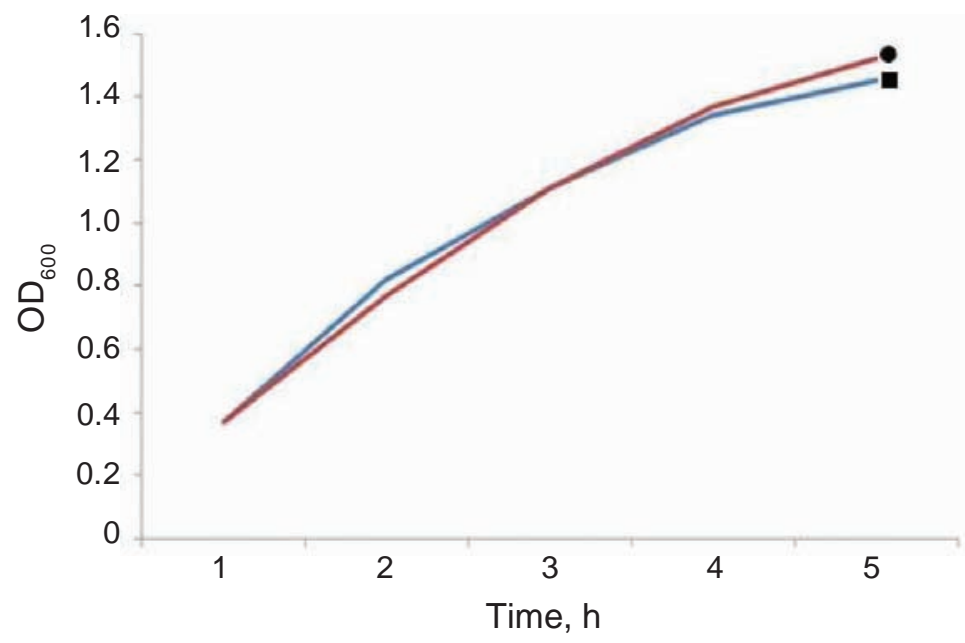

Fig. 4. Bacterial growth assessment. Bacterial growth patterns of recombinant and non-recombinant cells were detected and compared under induced conditions. Closed squire represents recombinant and closed circle represents non-recombinant bacteria 
the five helical affibody molecule has got considerably higher binding ability towards human HER 2 receptor as compared to double and triple helical structures. Comparison of the predicted binding data (1371.1 against 863.7 and 856.4) revealed that the five helical affibody has got the binding ability of about 1.6 times more than double or triple helical analogs. The duplication of helixes 1 and 2 resulted in binding ability of about 1.6 times more than that of the base structure ZHER2:2891.

In addition to size increase, a "GGGC" peptide sequence was also designed and located at the C-terminal end of affibody molecule. Based on previous reports, the use of cysteine-containing peptide-based chelators at the $\mathrm{C}$-terminus position of recombinant affibody molecules enable their site-specific labeling with the radionuclide. It has also been suggested that the position, composition and the sequence order of amino acid residues in peptide-based chelators influence labeling stability, cellular processing and bio-distribution of affibody molecules [11]. To date, several studies have been conducted to evaluate the efficacy of peptide-based chelators. Among them, the use of a-GGGC- sequence chelator at the C-terminal end of anti-HER2 "ZHER2:342" affibody molecule has been reported to enable its stable labeling with technetium and preserve its binding specificity [23]. Herein, as the first ever time report, two different types of modifications were performed in one affibody molecule to improve its affinity as well as the chelating and imaging property together. These may introduce the presently designed affibody as a good candidate for in vivo bio-functional studies.

Following the computational studies, to provide the experimental or industrial material, we successfully reported the heterologous expression of modified affibody molecule in the cytoplasm of $E$. coli cells without affecting the growth rates and patterns of recombinant bacteria. The typical triple helix anti-HER 2 affibody molecules have been already reported to be expressed as soluble product in the cytoplasm of bacterial cells [1]. Therefore, it is suggested that the present five helical affibody molecule with no signal peptide for periplasmic expression may also be expressed by E.coli systems. The collective improvement prediction of designed antiHER2 affibody along with its successful heterogeneous expression in bacterial cells is presented as the first ever time report. We hope it will be contributed in further biochemical studies and medical applications in the future.

Acknowledgments. The authors of this paper are thankful to the Research Institute for Fundamental Sciences (RIFS), University of Tabriz for the financial support.

\section{РОЗРОБКА, ДОКІНГ ТА ГЕТЕРОЛОГІЧНА ЕКСПРЕСІЯ AHТИ-HER2 АФІТІЛ}

\section{N. Salmanian Tabasi ${ }^{1}$, A. Gholizadeh ${ }^{1}$, B. Baghban Kohnehrouz ${ }^{2}$}

${ }^{1}$ Research Institute for Fundamental Sciences, University of Tabriz;

${ }^{2}$ Department of Plant Breeding and

Biotechnology, University of Tabriz; e-mail: aghz_bioch@yahoo.co.in

Афітіла - невеликі протеїнові ліганди, які продемонстрували важливі властивості за візуалізації і терапії пухлин. На нашу думку, структура і розміри молекул афітіл можуть бути модифіковані з метою збільшення їхньої здатності розпізнавання і афінного зв'язування 3 рецептором епідермального фактора росту людини типу 2 (HER2). Розроблена і охарактеризована нова платформа молекули афітіла, що складається 3 п'яти окремих спіралей (які кодують 99 амінокислот із дуплікатами спіралей 1 і 2 на $\mathrm{N}$-кінці та GGGC-хелаторною пептидною послідовністю на С-кінці) і сприяє зв'язуванню 3 HER2 із вищою авідністю. In silico проведено порівняльний аналіз структури та інтерактивного потенціалу розробленого афітіла. Також вивчено молекулярну експресію і продукування розробленого афітіла в клітинах Escherichia coli.

К л юч о в і с ло в а: афітіла, рецептор HER2, молекулярний докінг, експресія протеїну. 


\section{РАЗРАБОТКА, ДОКИНГ \\ И ГЕТЕРОЛОГИЧЕСКАЯ ЭКСПРЕССИЯ АНТИ-НЕR2 АФФИТЕЛ}

\section{N. Salmanian Tabasi ${ }^{1}$, A. Gholizadeh ${ }^{1}$, B. Baghban Kohnehrouz ${ }^{2}$}

\author{
${ }^{1}$ Research Institute for Fundamental \\ Sciences, University of Tabriz; \\ ${ }^{2}$ Department of Plant Breeding and \\ Biotechnology, University of Tabriz; \\ e-mail:aghz_bioch@yahoo.co.in
}

Аффитела, представляющие собой небольшие протеиновые лиганды, продемонстрировали важные свойства при визуализации и терапии опухолей. По нашему мнению, структура и размеры молекул аффител могут быть модифицированы с целью увеличения их способности распознавания и аффинного связывания с рецептором эпидермального фактора роста человека типа 2 (HER2). Разработана и охарактеризована новая платформа молекулы аффитела, состоящая из пяти отдельных спиралей (кодирующих 99 аминокислот с дупликатом спиралей 1 и 2 на $\mathrm{N}$-конце и GGGC-хелаторной пептидной последовательностью на С-конце) и способствующая связыванию с HER2 более высокой авидности. In silico проведен сравнительный анализ структуры и интерактивного потенциала разработанного аффитела. Также изучены молекулярная экспрессия и продуцирование разработанного аффитела в клетках Escherichia coli.

К л ю че в ы е с л о в а: аффитела, рецептор HER2, молекулярный докинг, экспрессия протеина.

\section{References}

1. Feldwisch J, Tolmachev V, Lendel C, Herne N, Sjöberg A, Larsson B, Rosik D, Lindqvist E, Fant G, Höidén-Guthenberg I, Galli J, Jonasson P, Abrahmsén L. Design of an optimized scaffold for affibody molecules. J Mol Biol. 2010; 398(2): 232-247.

2. Löfblom J, Feldwisch J, Tolmachev V, Carlsson J, Ståhl S, Frejd FY. Affibody molecules: engineered proteins for therapeutic, diagnostic and biotechnological applications. FEBS Lett. 2010; 584(12): 2670-2680.

3. Nord K, Nilsson J, Nilsson B, Uhlén M, Nygren PA. A combinatorial library of an alpha- helical bacterial receptor domain. Protein Eng. 1995; 8(6): 601-608.

4. Honarvar H, Jokilaakso N, Andersson K, Malmberg J, Rosik D, Orlova A, Karlström AE, Tolmachev V, Järver P. Evaluation of backbonecyclized HER2-binding 2-helix affibody molecule for in vivo molecular imaging. Nucl Med Biol. 2013; 40(3): 378-386.

5. Kronqvist N, Löfblom J, Jonsson A, Wernérus $\mathrm{H}$, Ståhl S. A novel affinity protein selection system based on staphylococcal cell surface display and flow cytometry. Protein Eng Des Sel. 2008; 21(4): 247-255.

6. Jonsson A, Wållberg H, Herne N, Ståhl S, Frejd FY. Generation of tumour-necrosis-factoralpha-specific affibody molecules capable of blocking receptor binding in vitro. Biotechnol Appl Biochem. 2009; 54(2): 93-103.

7. Wikman M, Steffen AC, Gunneriusson E, Tolmachev V, Adams GP, Carlsson J, Ståhl S. Selection and characterization of HER2/neubinding affibody ligands. Protein Eng Des Sel. 2004; 17(5): 455-462.

8. Orlova A, Magnusson M, Eriksson TL, Nilsson M, Larsson B, Höidén-Guthenberg I, Widström C, Carlsson J, Tolmachev V, Ståhl S, Nilsson FY. Tumor imaging using a picomolar affinity HER2 binding affibody molecule. Cancer Res. 2006; 66(8): 4339-4348.

9. Friedman M, Orlova A, Johansson E, Eriksson TL, Höidén-Guthenberg I, Tolmachev V, Nilsson FY, Ståhl S. Directed evolution to low nanomolar affinity of a tumor-targeting epidermal growth factor receptor-binding affibody molecule. J Mol Biol. 2008; 376(5): 1388-1402.

10. Tolmachev V, Rosik D, Wållberg H, Sjöberg A, Sandström M, Hansson M, Wennborg A, Orlova A. Imaging of EGFR expression in murine xenografts using site-specifically labelled anti-EGFR 111In-DOTA-Z EGFR:2377 Affibody molecule: aspect of the injected tracer amount. Eur J Nucl Med Mol Imaging. 2010; 37(3): 613-622.

11. Altai M, Wållberg H, Orlova A, Rosestedt M, Hosseinimehr SJ, Tolmachev V, Ståhl S. Order of amino acids in C-terminal cysteine-containing peptide-based chelators influences cellular processing and biodistribution of $99 \mathrm{mTc}$-labeled recombinant Affibody molecules. Amino Acids. 2012; 42(5): 1975-1985. 
12. Citri A, Yarden Y. EGF-ERBB signalling: towards the systems level. Nat Rev Mol Cell Biol. 2006; 7(7): 505-516.

13. Hynes NE, Lane HA. ERBB receptors and cancer: the complexity of targeted inhibitors. Nat Rev Cancer. 2005; 5(5): 341-354.

14. Tran TA, Rosik D, Abrahmsén L, Sandström M, Sjöberg A, Wållberg H, Ahlgren S, Orlova A, Tolmachev V. Design, synthesis and biological evaluation of a multifunctional HER2-specific Affibody molecule for molecular imaging. Eur $J$ Nucl Med Mol Imaging. 2009; 36(11): 1864-1873.

15. Xue X, Wang B, Du W, Zhang C, Song Y, Cai Y, Cen D, Wang L, Xiong Y, Jiang P, Zhu S, Zhao KN, Zhang L. Generation of affibody molecules specific for HPV16 E7 recognition. Oncotarget. 2016; 7(45): 73995-74005.

16. Ahlgren S, Orlova A, Rosik D, Sandström M, Sjöberg A, Baastrup B, Widmark O, Fant G, Feldwisch J, Tolmachev V. Evaluation of maleimide derivative of DOTA for site-specific labeling of recombinant affibody molecules. Bioconjug Chem. 2008; 19(1): 235-243.

17. Ren G, Zhang R, Liu Z, Webster JM, Miao Z, Gambhir SS, Syud FA, Cheng Z. A 2-helix small protein labeled with $68 \mathrm{Ga}$ for PET imaging of HER2 expression. J Nucl Med. 2009; 50(9): 1492-1499.

18. Lyakhov I, Zielinski R, Kuban M, KramerMarek G, Fisher R, Chertov O, Bindu L, Capala J. HER2- and EGFR-specific affiprobes: novel recombinant optical probes for cell imaging. Chembiochem. 2010; 11(3): 345-350.

19. Miao Z, Ren G, Liu H, Jiang L, Cheng Z. Cy5.5labeled Affibody molecule for near-infrared fluorescent optical imaging of epidermal growth factor receptor positive tumors. J Biomed Opt. 2010; 15(3): 036007.
20. Westerlund $\mathrm{K}$, Honarvar $\mathrm{H}$, Tolmachev V, Eriksson Karlström A. Design, Preparation, and Characterization of PNA-Based Hybridization Probes for Affibody-Molecule-Mediated Pretargeting. Bioconjug Chem. 2015; 26(8): 1724-1736.

21. Hwang H, Vreven T, Weng Z. Binding interface prediction by combining protein-protein docking results. Proteins. 2014; 82(1): 57-66.

22. Ohue M, Shimoda T, Suzuki S, Matsuzaki Y, Ishida T, Akiyama Y. MEGADOCK 4.0: an ultra-high-performance protein-protein docking software for heterogeneous supercomputers. Bioinformatics. 2014; 30(22): 3281-3283.

23. Wållberg H, Orlova A, Altai M, Hosseinimehr SJ, Widström C, Malmberg J, Ståhl S, Tolmachev V. Molecular design and optimization of $99 \mathrm{mTc}-$ labeled recombinant affibody molecules improves their biodistribution and imaging properties. J Nucl Med. 2011; 52(3): 461-469.

24. Eigenbrot C, Ultsch M, Dubnovitsky A, Abrahmsén L, Härd T. Structural basis for highaffinity HER 2 receptor binding by an engineered protein. Proc Natl Acad Sci USA. 2010; 107(34): 15039-15044.

25. Kelley L, Jefferys R. "Phyre2: Protein homology/ analogy recognition engine V 2.0". Structural Bioinformatics Group, Imperial College, London. 22 April 2011.

26. Ausubel FM, Brent R, Kingston RE, Moore DD, Seilman JG, Smith JA, Struhi R. Current protocols in molecular biology. (John Wiley \& Sons, Inc), 1991.

27. Laemmli UK. Cleavage of structural proteins during the assembly of the head of bacteriophage T4. Nature. 1970; 227(5259): 680-685.

Received 25.09.2017 